\title{
HOBSBAWN, Eric J. Como mudar o mundo: Marx e o marxismo, 1840-2011. São Paulo: Companhia das Letras, 2011.
}

\section{Gabriel Ferreira Carvalho* Édina Schimanski**}

Recebido em: 19/06/2012. Aceito em: 20/11/2012.

Eric Hobsbawm - historiador inglês nascido em 1917, em Alexandria, no Egito, quando este estava sob o domínio britânico, pode ser considerado como um dos pensadores mais importantes dos últimos tempos. Em 1933, depois da morte dos pais, muda-se para Londres. Nesse período há o crescimento do nazismo e Adolf Hitler já se torna uma figura definitivamente em ascensão na Europa. Hobsbawm, que era de origem judia, vem para Inglaterra para escapar da perseguição nazista e também para estudar na Universidade de Cambridge. Desde essa época, Marx e o marxismo se tornam para ele uma fonte profícua de estudos. Nos anos seguintes, ele torna-se militante político engajado e ingressa no Partido Comunista da Grã-Bretanha. Fez parte do Exército Britânico durante a II Guerra Mundial e com o fim desta volta para Universidade de Cambridge para seu doutoramento. Foi professor de História da Universidade de Londres, lecionando desde 1947 em Birkbeck College. Junto com outros renomados pensadores como Edward Thompson, foi representante da corrente historiográfica conhecida como História Social. Preocupado em entender o que ele chamou de "o breve século XX" escreveu diversos livros, entre eles destacam-se A Era das Revoluções (1962), A Era do Capital (1975), A Era dos Impérios (1987) e a Era dos Extremos (1994). De acordo com o jornal britânico The Guardian, Hobsbawm tem um livro em edição com título de Fractured Spring (tradução literal: Primavera Fraturada), com previsão de publicação para 2013.

Sua vida e obra são definidas por um traço marcante do pensamento marxista. Mesmo em tempos difíceis (como no período Stalinista, por exemplo), Hobsbawm permaneceu ligado ao Partido Comunista. Recentemente, em 01.10.2012, com a idade de 95 anos, falece em Londres. Sem dúvida, a humanidade perde um grande intelectual, porém seu extraordinário legado tende a permanecer na história.

Em sua última obra publicada, intitulada Como Mudar o Mundo: Marx e o marxismo, 1840 de 2011 (publicada pela Companhia da Letras, 2011), Hobsbawm faz uma releitura do passado marxista até chegar à atualidade. A referida obra se divide em duas partes.

Na primeira parte Hobsbawm apresenta a trajetória do pensamento socialista pré-marxiano, suas origens e a relação estreita de Marx com Engels e a política. Dada a importância dos elementos históricos presentes na época, ele faz uma análise das concepções políticas de Marx e Engels levando em consideração as lutas de classe, a revolução, as estratégias e as táticas do movimento socialista.

Neste contexto, Hobsbawm apresenta uma reflexão singular em relação à situação da classe trabalhadora na Inglaterra de Engels. Para Hobsbawm, o livro de Engels é ainda a melhor análise sobre a classe operária, embora deva ser compreendido como um livro para a sua época. Outro ponto de destaque apontado por Hobsbawm refere-se ao próprio Manifesto do Partido Comunista. Segundo ele, desde a Declaração dos Direitos do Homem e do Cidadão, o texto do Manifesto pode ser considerado como o mais expressivo politicamente, mesmo

\footnotetext{
* Mestrando do Programa Pós-Graduação em Ciências Sociais Aplicadas da Universidade Estadual de Ponta Grossa (UEPG). Graduado em Comunicação Social com habilitação em Jornalismo pela UEPG. Ponta Grossa, Paraná, Brasil. E-mail: gabrielcarven@gmail.com

"* Doutora em Educação, pela University of London - Institute of Education. Professora do Departamento de Serviço Social e do Programa de Pós-Graduação em Ciências Sociais Aplicadas da Universidade Estadual de Ponta Grossa (UEPG). Ponta Grossa, Paraná, Brasil. E-mail: edinaschi@uol.com.br
} 
com o fim do comunismo soviético e do declínio dos movimentos marxistas ao redor do mundo.

Adiante, Hobsbawm vai tratar da obra Grundrisse e sua trajetória e as dificuldades de publicação desta no cenário internacional. Ele considera Grundrisse como um preparativo importante para O Capital, bem como uma obra da maturidade intelectual de Marx.

Em seguida, o autor analisa as Formações Pré-Capitalistas e a importância que esta obra teve na análise e formulação do pensamento social e econômico de Marx e Engels sobre o capitalismo. Aqui, Hobsbawm pondera aspectos que poderiam ser retomados para o debate entre marxistas sobre a evolução histórica e os principais estágios de desenvolvimento. Dois pontos merecem destaque: 1) a simplificação a que a obra é muitas vezes submetida reduzindo as principais formações socioeconômicas a um único patamar, no qual todas as sociedades humanas sobem e chegam ao topo; e, 2) a omissão do chamado "modo asiático" das análises feitas pelos marxistas e a ampliação do "modo feudal" das interpretações sociais e econômicas.

No último tópico da primeira parte, Hobsbawm discute sobre a divulgação das obras de Marx e Engels. Em sua análise as obras consideradas clássicas podiam ser encontradas em qualquer sede do Partido Comunista ou Socialista. Muitas das obras de Marx e Engels publicadas, ou que se tornaram mais conhecidas, podiam ser discutidas por qualquer pessoa que conseguisse o acesso as mesmas.

A maioria das publicações e produções marxistas é da década de 1970. Mas, ainda assim, Hobsbawm argumenta que muitas das obras não estavam disponíveis nas línguas faladas em grande parte do mundo não socialista, porém as obras eram muito mais consumidas em locais onde as mesmas não eram proibidas pelo governo.

$\mathrm{Na}$ segunda parte do livro, Hobsbawm apresenta reflexões sobre as críticas feitas ao marxismo na Inglaterra e no mundo. Segundo ele, as obras de Marx mesmo volumosas tem uma dimensão limitada. Assim, tanto os textos que fazem a crítica quanto à defesa de Marx tem se tornado repetitivos no decorrer do tempo. Destacam-se nesse ponto as críticas de Marshall a Marx, as quais segundo Hobsbawm eram habitualmente hostis e oblíquas. Muito embora,
Marshall não tenha começado com apreciações fechadas sobre Marx.

Hobsbawm destaca a crise do capitalismo e a influência de Marx na expansão dos movimentos socialistas e operários, inclusive no período que antecedente à Revolução Russa. Outros momentos importantes nesse contexto histórico são o debate revisionista e a crise do marxismo.

A partir dos anos 1930 a propagação do marxismo foi um fenômeno paradoxal. Por um lado, ela incidiu de forma local à medida que aconteceu independentemente de forças externas, isto é de ideias importadas. Por outro lado isso fez com que assumisse uma forma padronizada. Neste contexto, a Era do Antifascismo, conforme denominada por Hobsbawm, que dominou uma grande parte do pensamento intelectual ocidental, inicia-se associada a uma crise política, a qual leva muitos intelectuais na luta contra Hitler e o nazismo. Mas, intelectuais de origem burguesa não eram tão atraídos pelo tipo de pensamento propagado pela Internacional Comunista. Muitos deles se alinhavam muito mais com ideias mais próximas aos trotskistas. No campo da Literatura e das Artes o pensamento internacional era mais comum, partilhavam escritores e artistas que podiam ser identificados com o comunismo ou pelo menos que haviam se comprometido com o antifascismo.

Hobsbawm dedica diversos trechos, na segunda parte do livro, a Antônio Gramsci e a teoria política do autor italiano, atentando para a importância da obra por ele deixada e, também, por sua contribuição para com o socialismo e o marxismo. Para ele, Gramsci dentre os marxistas, foi o que mais percebeu com propriedade o papel da política na sociedade e que esta está além do poder. Isto em termos de análise histórico-política ganha um contorno imprescindível para a prática, sobretudo para os socialistas.

Por fim Hobsbawm apresenta sua visão sobre as crises e a recessão mundial e concepções sobre Marx e o trabalhismo. Fica claro na análise do autor que depois de um século da morte de Marx, o marxismo entra em recessão. A queda do modelo soviético foi, segundo ele, traumática para os comunistas e socialistas.

Em relação ao trabalhismo, ele argumenta que a contribuição fundamental de Marx e 
Engels estaria na ideia de organização da classe camponesa sob a forma de partido político ativo.

Como Mudar o Mundo: Marx e o marxismo, 1840 de 2011 é uma obra escrita para ser lida por pessoas que pretendem se aprofundar no debate das ideologias e do marxismo através da História. Os leitores e as leitoras da obra, entretanto, não podem deixar-se enganar pelo título reminiscente do livro. Não se trata aqui de um manual ou um de um step by step of a revolution guide, mas sim de uma obra densa onde Hobsbawm traz a tona o mais profundo do pensamento marxista através das décadas, encarando fatos contundentes para o marxismo como o fim da União Soviética, por exemplo. Assim, conforme o autor, as contradições experimentadas nesse último século apontam para algo positivo - finalmente redescobriu-se que capitalismo "não é a solução, mas o problema” (HOBSBAWM, 2011, p.374).

Como já foi dito acima, o livro é o último publicado antes de sua morte, em outubro deste ano, e pertence à vasta produção bibliográfica de Hobsbawm. O autor encontra a morte mantendo firme a convicção de um axioma que pretende muito mais que discutir a sociedade, mas que visa entender o cerne de Marx e do socialismo. A ideia cunhada no livro é a de um debate e uma análise das teorias marxistas, sem associar as mesmas a qualquer modelo prático. O fundamental não é discutir regimes socialistas, mas a essência socialista a partir de Marx e marxistas e toda influência em diversos setores das ciências e artes ao redor do mundo. 